\title{
EVALUATION OF THE APPLICATION OF MUNICIPAL SOLID WASTE INCINERATOR (MSWI) ASH IN CIVIL ENGINEERING USING A SUSTAINABILITY APPROACH
}

\author{
Setareh Seraj *, Morteza Nikravan, Ali A. Ramezanianpour and Parham Zendehdel
}

Department of Civil and Environmental Engineering, Amirkabir University of Technology, Tehran, Iran
Article Info:
Received:
2 March 2018
Revised:
15 September 2019
Accepted:
25 October 2019
Available online:
23 March 2020
Keywords:
MSWI ashes
Sustainability index
MIVES
AHP
Pairwise comparison
Hierarchy
MSWM scenarios

\begin{abstract}
Incineration is regarded as one of the common methods for energy recovery as well as waste reduction, due to the high amount of waste generation in major cities; for instance Tehran (7000-8000 ton/day), and lack of sufficient landfill. The proper treatment and recycling of municipal solid waste incinerator (MSWI) residual ashes is one of the challenges which decision makers are faced with. In order to investigate the feasibility of the recycling of ashes, the sustainability index is considered. This evaluation is carried out by means of the multi-criteria decision-making approach for assessing sustainability (MIVES) and the Analytical Hierarchy Process (AHP) as a conventional decision-making tool. Six possible scenarios in Iran was determined, BA/FA landfilled with solid waste system (current scenario), Partial substitute of raw materials for cement/concrete, Ceramics and glass/glass-ceramics production, Geotechnical applications, use of BA/FA as alternative adsorbent and Fertilizers in agricultural soils. The assessment was accomplished through 25 questionnaires distributed among experts which includes environmentalists, governmental decision makers, academics, and technical groups. The questionnaires comprised of 33 pairwise comparison matrices, and the experts were asked to systematically compare elements of the constructed hierarchy in numerical terms. According to the results, reusing MSWI ash as a partial substitute for raw materials in cement/concrete scored highest in ranking among other potential MSWM scenarios (with a relative weight of 0.234 ). The results also reveal that the utilization of BA/FA as alternative adsorbents and as fertilizers in agricultural soils are not to be currently pursued in Iran (with relative weights of 0.117 and 0.129 respectively).
\end{abstract}

\section{INTRODUCTION}

On a global scale, urbanization has accelerated the generation of municipal solid waste (MSW) (Khajuria, 2010) (Talyan, 2008). Thus, disposal methods have become an increasingly important issue (Sabbas, 2003). As observable in Figure 1 and 2, an approximate trend is visible which indicates the relevancy between the amount of generated and incinerated waste. It is also noticeable that countries with higher levels of waste generation employ a wider spectrum of waste management approaches. Such diverse waste management approaches are shown in Table 1.

MSWI waste management is a subject of global debate. It has been shown globally that Waste-to-energy incineration process is a feasible management strategy for unrecyclable municipal solid waste (MSW) treatment and it is increasing by years.

The incineration process creates waste ashes; depending on the incineration process, about 80 to 90 percent of
MSWI ash is comprised of bottom ash (BA), and 10 to 20 percent is fly ash (FA) by weight (Tasneem, 2014). BA is considered as non-hazardous waste; nevertheless, FA is frequently regarded as hazardous waste containing heavy metals and chloride ions, which commonly requires suitable pre-treatment prior to landfilling and reuse in construction (Margallo et al, 2015). MSWI residues are prone to recycling, given that they possess properties which are applicable in many fields (Hoornweg \& Bhada-tata, 2012; Wiles \& Shepherd, 1999; Forteza et al., 2004).

Due to the high cost of treatment and disposal and the imminent shortage of landfill space, the interest in potential reuses of BA and FA has been increasing in recent years (Forteza et al., 2004; Sormunen, 2016; Sun Li et al., 2016; Travar et al., 2009; U.S. EPA, 2016). In Iran, the first incinerator was employed in 2014 and currently, about 200 ton/ day of 8500 ton/day generated solid waste is incinerated (Nabavi-Pelesaraei et al., 2017). Thus, Iran is a country that 
still has to pave the road of dealing with MSW incineration recycling in a noteworthy way. In terms of sustainability, there is a need to reduce consumption of global reserves of raw materials. The evolution of landfill diversion and closedloop production models of waste as a resource material are initial steps towards Circular Economy (CE) thinking, which is increasing among European companies involved in sustainable materials management (Silva et al., 2016).

To incorporate environmental considerations in the development of MSWI ash recycling and reuse; authors employed a sustainability index (Pires et al., 2011). The success of sustainable development lies in the availability of standards by which we can compare and assess the sustainability index of any given alternative scenarios. Besides, it is very important for designing relevant policy for further improving the overall efficiency of solid waste management (Chen, 2014).

An appropriate method of assessment of sustainability is required to evaluate the management of MSWI solid residual. Many researchers have evaluated the sustainability index for solid waste management (MSW) in previous studies (Oehmig et al., 2015; Allegrini et al., 2015; Huang et al., 2015; Tasneem, 2014; Sou et al., 2016; Margallo et al., 2013; Travar et al., 2009). However; their common deficiency is the lack of emphasis on social aspects. Assessing the social aspects is of major significance since it facilitates decision-makers and the public in defining social ideals, linking them to clear objectives and targets and it eases the calculation of the impact of these activities on the environment and society.

This study attempts to address the suitable option for MSWI ash recycling in Iran with regard to technical feasibility, economy, environmental and social aspects. In addition, the multi-criteria decision-making approach for assessing sustainability (MIVES) is used to evaluate the sustainability index of MSWI ash reuse alternatives in civil engineering.

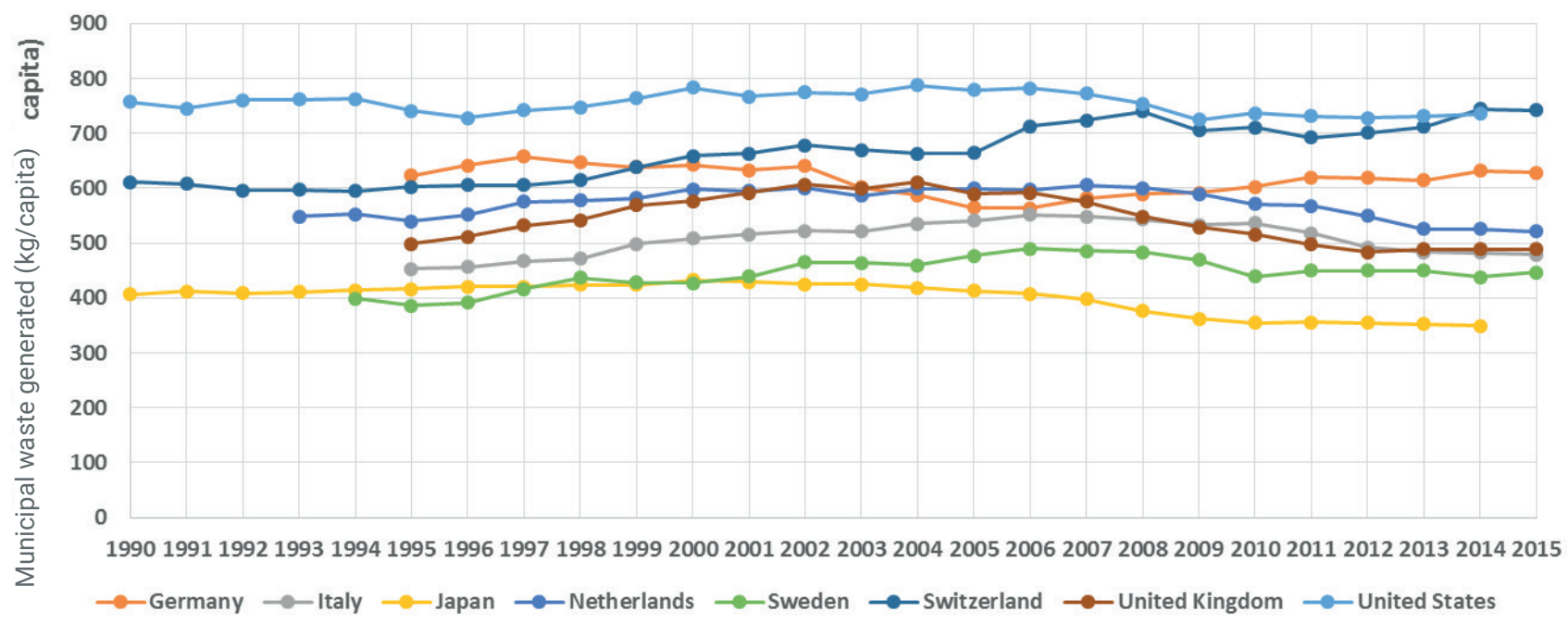

FIGURE 1: Annual municipal solid waste generation per capita in some European countries, Japan and the U.S ("http://stats.oecd.org/," 2017).

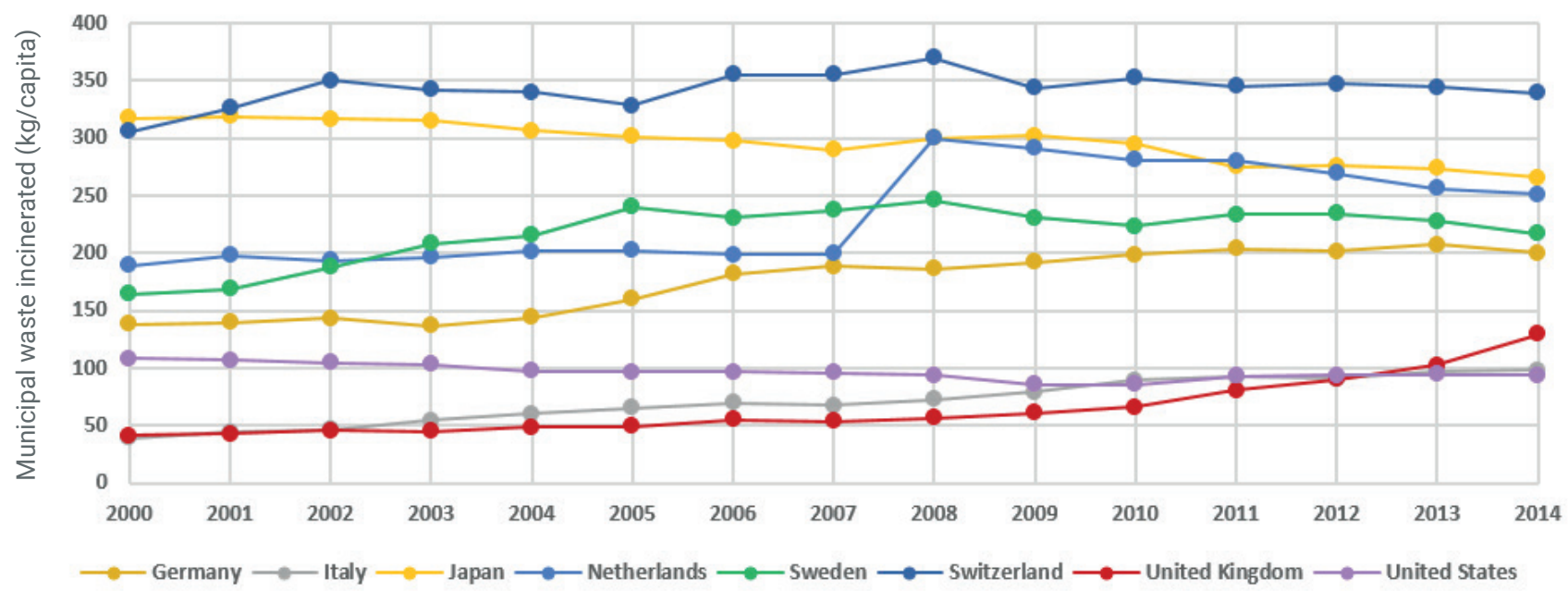

FIGURE 2: Annual municipal solid waste incinerated per capita in some European countries, Japan and the U.S ("http://stats.oecd.org/," 2017). 


\section{METHODS AND MATERIAL}

The initial steps of this study aimed to review existing previous studies on solid residual from municipal solid waste incineration. After establishing varying viewpoints on waste incineration ashes, this paper attempts to provide assessment context for MSWI ash reuse in exemplary civil engineering fields by compiling a list of relevant sustainability criteria. Subsequently, the ideal analysis method with specific regards to the determined criteria and study goals is opted. Ultimately, the most appropriate scenario for reusing MSWI ash in Iran is proposed (Figure 3).

\subsection{Applications of MSWI Ash}

A considerable number of studies has implemented a systematic approach towards the beneficial utilization of MSWI ashes in European and Asian countries (Tasneem, 2014; Colangelo et al., 2012). Both BA and FA have been treated and furthermore successfully employed in civil engineering applications in varying forms and to various extents. For instance, BA is employed in road construction and embankment fill (Oehmig et al., 2015; Margallo, 2015). In addition, due to its pozzolanic reactivity, FA can be used as a substitute for lime or cement in soil stabilization (Lam et al., 2010; Tasneem, 2014). From the environmental perspective, these applications are promising and effective provided that technical feasibility is ensured. There is a broad spectrum of MSWI residue management approaches that are summarized in (Table 1) (Tasneem, 2014; Ørnebjerg, 2006).

\subsubsection{Cement/Concrete Application}

MSWI ash (fly and bottom ash) can be reused as a partial substitute for raw materials in cement/concrete production. Experimental results approved the possibility of casting concrete with a combined mix of MSWI bottom ash and fly ash as aggregates (Ginés et al., 2009).

The potential MSWI fly ash application in concrete is ei- ther as a replacement for cement or as a substitute for aggregate. Nonetheless, the addition of fly ash in cement will increase chloride and heavy metal concentrations(Ferreira et al., 2003). Moreover, bottom ash also possesses certain properties intended for reuse as a partial substitute for cementitious material due to its chemical components like $\mathrm{CaO}, \mathrm{SiO}_{2}, \mathrm{Al}_{2} \mathrm{O} 3, \mathrm{Fe}_{2} \mathrm{O}_{3}$ that are similar to that of cement, but only after appropriate chemical treatment (Tasneem, 2014; Li, 2016).

\subsubsection{Ceramic/Glass}

Generally, the term 'ceramics' (ceramic products) is used for inorganic materials (with possibly some organic content), made up of non-metallic compounds which are hardened through firing processes (Barros, 2007). Consumption of silicate-based natural raw materials is predominant in the ceramic industry, which enables the consideration of MSWI ash as a surrogate, given that it is a silicate-rich substance. This fact renders the reuse of MSWI ash in a ceramic industry highly suitable(Ferreira et al., 2003). Glass ceramics are products with enhanced properties and higher market value which have unique applications, e.g. in the aeronautics industry.

\subsubsection{Roads}

Road construction entails vast amounts of natural aggregates. Studies demonstrated the possible reuse of MSWI ash in road construction, with BA being a more suitable candidate for its physical characteristics, whereas FA is considered as a secondary alternative due to its soluble salt and heavy metal contents (Margallo, 2015). The calculations clearly indicate that there are economic and environmental advantages in using waste in roads, including significant savings in costs, reduction in $\mathrm{CO}_{2}$ emission, and energy consumption (Poulikakos et al., 2017). R. Forteza (Forteza et al., 2004) concluded that bottom ash is an exceptional substitute material for granular layers (bases and sub-bases) with regards to refined particle size distribution.

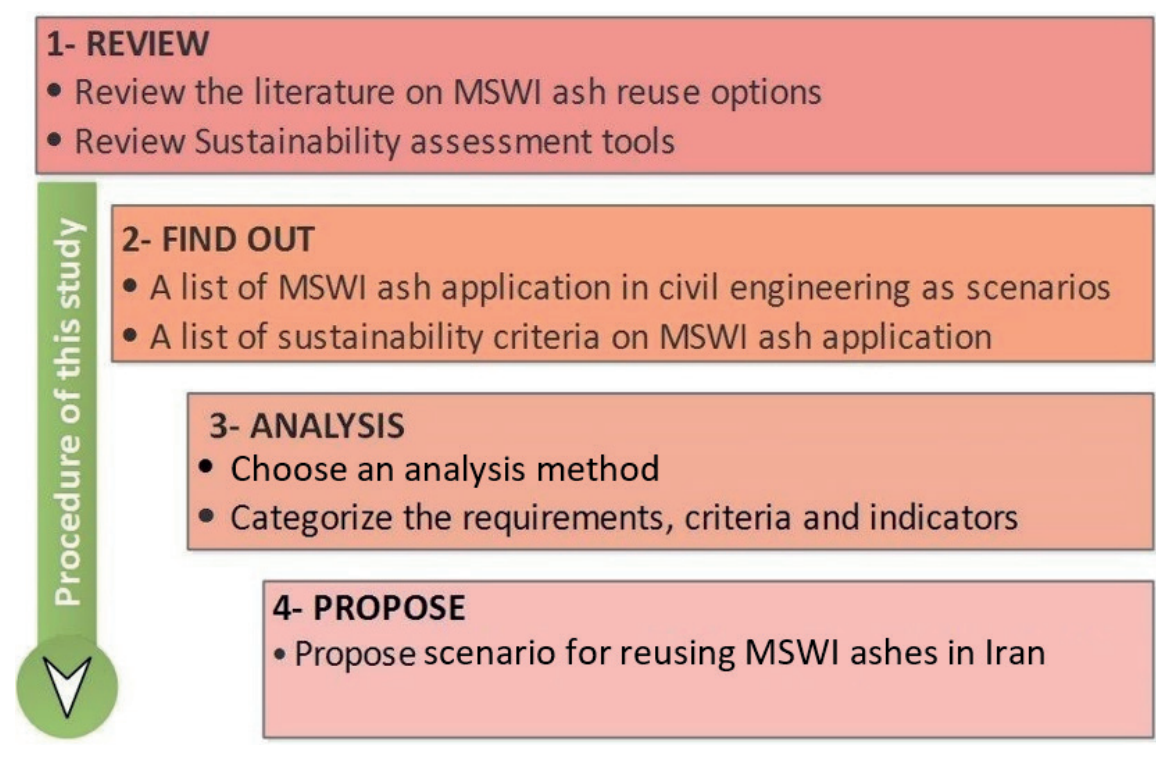

FIGURE 3: Procedure of this study. 
TABLE 1: The management of MSWI ash in several countries (Ørnebjerg et al., 2006; Tasneem, 2014; Chandler, 2007; Vehlow, 2012).

\begin{tabular}{|c|c|c|c|c|c|c|}
\hline Country & BA recycled & BA treatment & BA application & FA recycled & FA treatment & FA application \\
\hline Netherlands & $80 \%$ & $\begin{array}{l}\text { ferrous and } \\
\text { non-ferrous metal } \\
\text { recovery, size } \\
\text { reduction }\end{array}$ & $\begin{array}{l}\text { embankment fill, } \\
\text { road base, disposal } \\
\text { into landfill }\end{array}$ & $30 \%$ & - & $\begin{array}{l}\text { filler material in } \\
\text { asphalt as the } \\
\text { alternative of } \\
\text { limestone }\end{array}$ \\
\hline Denmark & $98 \%$ & $\begin{array}{l}\text { screening, crush- } \\
\text { ing, and ferrous } \\
\text { metal recovery, } \\
\text { gravel substitute as } \\
\text { subbase material }\end{array}$ & $\begin{array}{l}\text { building, road } \\
\text { construction, } \\
\text { embankment fill }\end{array}$ & $\begin{array}{l}\text { exports APC } \\
\text { residue to Norway } \\
\text { or Germany }\end{array}$ & - & $\begin{array}{l}\text { required to landfill } \\
\text { after treatment }\end{array}$ \\
\hline Germany & $65 \%$ & $\begin{array}{l}\text { reduction of salt } \\
\text { content by water } \\
\text { quenching, ferrous } \\
\text { and non-ferrous } \\
\text { metal recovery, } \\
\text { 3-month matu- } \\
\text { ration }\end{array}$ & $\begin{array}{l}\text { road construction } \\
\text { and secondary } \\
\text { building materials }\end{array}$ & small quantity & stabilization & $\begin{array}{l}\text { disposed into } \\
\text { landfill }\end{array}$ \\
\hline France & $79 \%$ & $\begin{array}{l}\text { ferrous and } \\
\text { non-ferrous metal } \\
\text { removal, size re- } \\
\text { duction, and some- } \\
\text { times cement, } \\
\text { stabilization }\end{array}$ & civil constructions & - & $\begin{array}{l}\text { cement and chem- } \\
\text { ical stabilization } \\
\text { using } \mathrm{NaHCO}_{3^{\prime}} \\
\text { Thermal treatment }\end{array}$ & $\begin{array}{l}\text { disposal into land- } \\
\text { fill designated for } \\
\text { hazardous waste }\end{array}$ \\
\hline
\end{tabular}

\subsubsection{Embankment}

Embankments are constructed from soil or stone materials which are employed to restrain water. When soils do not display desirable geotechnical properties, it is common practice to stabilize them with lime or cement (Margallo, 2015). FA can be regarded as a replacement for lime or cement due to its pozzolanic reactivity (Garcia-Lodeiroet al., 2016), thus FA could be potentially reused as a stabilizer in embankments after treatment. R. Forteza (Forteza et al., 2004) inferred that bottom ash is classifiable as adequate soil for embankments and landfilling. The common challenging environmental issue of MSWI ash application in embankments and roads is pollutant exposure to soil and water systems (Margallo, 2015).

\subsubsection{Adsorbent}

The amount of colored wastewater has been increasing since industries like textile, paper, food, and cosmetics use dyes to color their products (Margallo, 2015). There are different ways to remove dyes (biological, chemical and physical), and adsorption is one of the most effective physical methods for color removal, in spite of it being a high-cost process. Instead of using commercial activated carbon or zeolites, Wang (Wang \& Wu, 2006) proposed using fly ash for the adsorption of NOx, SOx, organic compounds, mercury in the air, cations, anions, dyes and other organic substances in water.

\subsubsection{Agriculture}

Nitrogen, phosphorus, and potassium are the three main elements commonly required for vegetative growth, hence the application of fertilizers to enrich the soil and assist plant growth is a common practice (Ferreira et al., 2003). In a general sense, MSWI BA and FA are rich in nutrients and this makes their use as fertilizers in agricultural soils possible. Agricultural utilization of MSWI ashes is an immensely controversial subject and some MSWI ashes, especially FA, are restricted to agricultural use given their heavy metal content. However, with appropriate treatment, the utilization of MSW ash will grow, which could subsequently lead to the reduction in commercial fertilizer usage (Margallo, 2015).

\subsubsection{Landfill Cover}

A landfill cover is a multilayer system that serves to reduce the emission of landfill gas into the atmosphere and the infiltration of water into the waste (Travar et al., 2009). Due to the conservation of natural resources, an alternative material possessing desired physical characteristics, like MSWI ash can be employed in landfill covers.

Furthermore, some studies show that FA heavy metal content improves biogas production in landfills (Mari'a Margallo, 2015). Similar to the aforementioned issues, this application too, faces serious environmental concerns due to leaching and release of contaminants (heavy metals) (Travar et al., 2009).

\subsection{Sustainability tools}

Due to the breadth of subject and effectiveness of various factors involved, a comprehensive assessment methodology is required. MIVES (Modelo Integrado de Valor para una Evaluacion Sostenible or Integrated Value Model for Sustainability Assessment) is a multi-criteria decision-making method (MCDM) that constructs a value function on the basis of the utility theory. MIVES offers three key advantages over other frequently used MCDMs, in that it is time-independent; it is adjustable and can be modified to take all the stakeholders' demands into account through simple adjustments to the requirements tree's items and their weights (Hosseini et al., 2018) ;and it is flexible and can be applied to myriads of fields with varying characteristics and conditions. As far as now, MIVES has already been used for the energy sector (Barros et al., 2015), urban planning (Pujadas et al., 2017; Piñero et al., 2017), buildings (Pons \& Aguado, 2012; Lombera \& Rojo, 2010), public infrastructures (Par- 
do-Bosch \& Aguado, 2016), sewage systems (de la Fuente et al., 2016), wind towers (de la Fuente et al., 2017), and civil and architect projects (Pons et al., 2016). MIVES helps to consider potential nonlinearities in the evaluation and it integrates AHP (Analytical Hierarchy Process). The Analytical Hierarchy Process (AHP) is a decision-aiding method. This approach enables the decision maker to organize tangible and intangible elements and offers a structured and simple solution to the decision-making problems (Al-Harbi, 2001). AHP provides element weighting so that the system is organized according to the opinions returned by a group of experts regarding the relative importance of elements, whereas MIVES is used to produce value functions in order to transform indicators measured in different units into a value index. The diversity of these cases, some at an energy or urban level, some about building elements, some assessing broad samples in general, and some carrying out analysis in detail, etc., shows MIVES's adaptability.

Moreover, as observable in (Blanco et al., 2017; Aguado et al., 2016; Fuente et al., 2016), the most commonly used method of assessment is the AHP method and MIVES, which is multivariate which is capable of incorporating multiple sustainability indexes in the sustainability assessment and multilateral which covers a diverse variety of sustainability problems. According to (Pérez, 1995) AHP possesses a firm theoretical foundation and its viability has been illustrated through operations of all kind (Governmental agencies, Corporations, consulting firms). Besides, AHP allows the comparison of several criteria and is capable of checking the inconsistency of expert judgments. Along with intangibles such as political and social factors, tangibles like economic and technical factors can also be considered with this method.

\subsection{Sustainability approach}

This study employs a combination of the MIVES and AHP method to assess the sustainability of various MSWI ash management options. This Method involves plugging the environmental, economic, social and technical feasibility aspects of any scenario into an assessment evaluation framework. Six different MSWI ash management scenarios were proposed and furthermore, compared in this study, based on a broad range of beneficial utilization of MSWI ash mentioned earlier. The potential MSWI ash management scenarios are as follows:

0 . BA/FA landfilled with solid waste (current system);

1. Partial substitute of raw materials for cement/concrete;

2. Ceramics and glass/glass-ceramics production;

3. Geotechnical applications including road construction, embankment and landfill cover materials;

4. Use of BA/FA as alternative adsorbent;

5. Fertilizers in agricultural soils.

According to the work of Blanco (Blanco et al., 2016), the current model also requires defining three basic terms, namely; The system boundaries, Tree requirements, The value functions that will turn Physical units or features of each index to a value between 0 and 1 . Nonetheless, given that the present indexes are not of binary nature, AHP is used in order to assign a weight to each element of the requirements tree.

The analytical hierarchy is typically comprised of four levels (Goal, criteria, sub-criteria, and alternatives). The criteria are the environmental (C1), economic (C2), social aspects (C3) and technical feasibility (C4) of any given scenario.

Initially, a proper hierarchy of the AHP model containing the goal, four major decision criteria and 28 sub-criteria that have been selected due to their thematic affinity with the criteria and six goal-orientated alternative scenarios, was structured (Figure 4). Likewise, Yin (Yin et al., 2016) employed similar AHP criteria (environmental, technical, economic and social indicators) to evaluate four MSWM scenarios, including waste incineration, in the northern region of China. Dong (Dong et al., 2014) has also pursued an energy-efficient, environmentally friendly and economically affordable MSWM system via multi-criteria decision making (MCDM) using three main criteria (energy, environment and economy) based on life cycle assessment and life cycle cost inventories.

Defining the criteria is very vital in problem-solving. Sustainable strategies for MSWM entail precise objectives to be conveyed and applicable measures to be taken with regards to the political, social, financial, economic, and technical aspects of waste management (Schübeler et al., 1996).

The environmental impacts of MSWM systems should be considered because if managed inappropriately, waste poses a risk to human health and the environment.

Social acceptance is significant in all stages of waste management, from the conceptual stage to the implementation, including behavior upgrading. Social acceptance is encouraging the active participation of social actors in the decision-making process.

Technical feasibility has to be taken into attention on the basis of whether the suitable resources are existing or reasonably accessible to implement a specific alternative.

Economic aspects should never be overlooked in decision making, as the economic evaluation of the total cost of owning and operating a facility over a period of time is one of the most major criteria in engineering. The numbers in parentheses (relative weights) are obtained through the weighting process using the AHP method and are the result of the final analysis. The relative weights of the criteria represent their local priority with respect to the goal. Likewise, the relative weights of the sub-criteria are obtained with respect to their corresponding criteria and exhibit a distribution of local priority within each criterion.

Furthermore, questionnaires were distributed among individuals or organizations representing four interest expert groups. The four expert groups include:

(a) Environmentalists (environmental activists in NGO's);

(b) Governmental decision makers (local government officials); 
En5: Local and Global ecosystems (0.087)

En6: Availability of resources $(0.065)$

\section{E7: Human health} (0.259)

En8: Air pollution (0.129)

En9: Energy consumption (0.054) ocial learning $(0.075)$

S5: Flexibility and adoptability (0.079)

S6: Functionality and usability (0.108)

\section{S7: Modularity (0.069)}

S8: Intergenerational Equity (0.106)

S9: Social awareness S9: Social awareness
$(0.087)$

S10: Ecological awareness $(0.090)$

En10: Water consumption (0.085)

FIGURE 4: Hierarchy of the AHP model for the proposed MSWM in Iran.

(c) Academics (professors in major universities of Iran);

(d) Technical groups (operative and technical staff of waste management facilities in Tehran).

The results were calculated using the Expert Choice ${ }^{\circledR}$ software. Expert Choice ${ }^{\circledR}$ is a commercially available decision-making software which implements the analytical hierarchy process (AHP) based on the model hierarchy and pairwise comparison matrices as data inputs. Pairwise comparisons between the criteria and each set of sub-criteria were conducted in order to carry out the weighting of each component. Subsequently, the obtained weights were aggregated to establish a prioritization of alternatives, the maximum value of which is to be considered the preferred alternative. There is no need to implement analysis steps manually since Expert Choice ${ }^{\circledR}$ simplifies the implementation of the AHP steps and automates many of its computations (Al-Harbi, 2001; Ishizaka \& Labib, 2009).

The main goal of the developed model is to evaluate the most sustainable MSWI ash management in Iran by calculating its sustainability index. In order to devise an optimal problem-solving algorithm, a precise definition of the sub-criteria is required. The environmental impacts of
MSWI ash management options have to be carefully taken into account and if managed improperly, they may pose a threat to human health and the environment.

Economic aspects are a matter of utter importance in decision making (Hacer, 2015). The monetary issues are evaluated under the capital and operating costs sub-criteria in this study.

Social aspects of MSWM play a notable role in all stages of waste management, from the conceptual stage all the way through to the implementation (Hacer, 2015). Social aspects facilitate the active participation of social actors in the decision-making process.

Technical feasibility should also be accounted for, based on the probable availability of the required resources or reasonable accessibility to implement a specific alternative. The corresponding sub-criteria for each of the above criteria are demonstrated in Table 5. The important factor of each criterion and sub-criterion was established by the target experts through completing questionnaires. These questionnaires only comprise of pairwise comparison matrices $(n \times n)$ for each of the lower levels and one matrix for each element in the level immediately above, by using the relative scale measurement shown in Table 2 (Saaty, 2008). 
The pairwise comparison matrix (PCM) for a set of $n$ criteria $\left\{C_{i} / 1 \leq i \leq n\right\}$ is constructed as follows:

$[P C M]_{n \times n}=\left[\begin{array}{cccc}r_{11}=C_{1} / C_{1} & r_{12}=C_{1} / C_{2} & \cdots & r_{1 n}=C_{1} / C_{n} \\ r_{21}=C_{2} / C_{1} & r_{22}=C_{2} / C_{2} & \cdots & r_{2 n}=C_{2} / C_{n} \\ \vdots & \vdots & \cdots & \vdots \\ r_{n 1}=C_{n} / C_{1} & r_{n 2}=C_{n} / C_{2} & \cdots & r_{n n}=C_{n} / C_{n}\end{array}\right]=\left[r_{i j}\right]_{n \times n}$

Each element of the pairwise comparison matrix $r_{i, j}=$ $C_{i} / C_{j}$ represents the relative importance of one criterion to another. Given the structure of the PCM, an intrinsic reciprocal feature of the PCM is observed. This feature is mathematically defined as following:

$r_{i j}=1 / r_{j i} \quad \forall i, j=1, \ldots, n$

In the next step (Al-Harbi, 2001), hierarchical synthesis is used to weight the eigenvectors regarding the weights of the criteria and the summation of all weighted eigenvector entries corresponding to those in the next lower level of the hierarchy. Synthesizing the pair-wise comparison matrix is achieved by dividing each element of the by its column total:

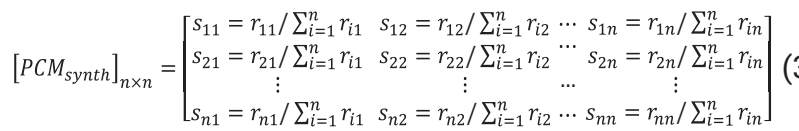

Moreover, the weight vector is determined by finding the row averages of the synthesized pair-wise comparison matrix:

$[w]_{n \times 1}=\frac{1}{n}\left[\begin{array}{c}\sum_{i=1}^{n} s_{1 j} \\ \sum_{i=1}^{n} s_{2 j} \\ \vdots \\ \sum_{i=1}^{n} s_{n j}\end{array}\right]=\left[\begin{array}{c}w_{1} \\ w_{2} \\ \vdots \\ w_{n}\end{array}\right]$

Given that $[w]_{n \times 1}$ represents the weight vector and $\lambda_{\max }$ is the principle eigenvalue of the pairwise comparison matrix $[P C M]_{n \times n}$, the following product matrix is generated:

$[P]_{n \times 1}=[P C M]_{n \times n} \cdot[w]_{n \times 1}$

$\left[\begin{array}{c}p_{1} \\ p_{2} \\ \vdots \\ p_{n}\end{array}\right]=\left[\begin{array}{cccc}r_{1,1} & r_{1,2} & \cdots & r_{1, n} \\ r_{2,1} & r_{2,2} & \cdots & r_{2, n} \\ \vdots & \vdots & \cdots & \vdots \\ r_{n, 1} & r_{n, 2} & \cdots & r_{n, n}\end{array}\right] \cdot\left[\begin{array}{c}w_{1} \\ w_{2} \\ \vdots \\ w_{n}\end{array}\right]$

Furthermore, in order to obtain $\lambda_{\text {max }}$ the following equation is perturbed:

$\lambda_{\max }=\frac{1}{n} \sum_{i=1}^{n} \frac{p_{i}}{w_{i}}$

Another feature of pairwise comparison matrices larger than $(3 \times 3)$ is referred to as the consistency condition. This condition is expressed as follows:

$r_{i k}=r_{i j} r_{j k} \quad \forall i, j, k=1, \ldots, n$

If and only if this condition is satisfied, then the obtained weighted ranking is in complete agreement with the expressed preferences and the PCM is consistent. In addition, with respect to (Saaty, 2008), it is necessary to determine consistency by means of the eigenvalue $\lambda_{\text {max' }}$ and furthermore calculating the consistency index $C I$ as follows: $C I=\left(\lambda_{\max }-n\right) /(n-1)$, where $n$ is the corresponding
TABLE 2: Pair-wise comparison scale for AHP preference (Saaty, 2008; Al-Harbi, 2001).

\begin{tabular}{|c|c|}
\hline $\begin{array}{l}\text { Intensity of } \\
\text { importance }\end{array}$ & Definition \\
\hline 9 & $\begin{array}{l}\text { When one activity is extremely more important than the } \\
\text { other }\end{array}$ \\
\hline 8 & Very strongly to extremely \\
\hline 7 & Very strong or demonstrated importance \\
\hline 6 & Strongly to very strongly \\
\hline 5 & Strong or essential importance \\
\hline 4 & Moderately to strongly \\
\hline 3 & Moderate importance of one over another \\
\hline 2 & Equally to moderately \\
\hline 1 & When two criteria are of equal importance to the objective \\
\hline
\end{tabular}

matrix size. The consistency evaluation is completed by calculating the consistency ratio $C R$ as follows: $C R=C I / R I$, where $R I$ represents the random consistency index derived from Table 3.

Providing $C R$ exceeds 0.10 , the judgment matrix is inconsistent (not consistent), and judgments should be reviewed and improved. All of the above mentioned steps should be taken for all levels in the hierarchy.

\section{RESULTS AND DISCUSSION}

As discussed above, the questionnaires distributed among four target groups were collected and were further used as a foundation for Expert Choice ${ }^{\circledR}$ inputs. As depicted in Figure 3, the lowest level of the hierarchy comprises of six proposed MSWM scenarios. As depicted in table 4, the results reveal the following ranking of the scenarios: $1>2$ $>3>0>5>4$ with the overall inconsistency of 0.01 that is less than 0.1 , thus validating decision maker judgements. According to the analyzed data, the currently active MSWM practice in Iran which consists of landfilling has a sustainability index of (0.154). Scenario 1 proposes the function of MSWI ash as a partial substitute for raw materials in cement/concrete, which results in a remarkable change in the sustainability index (0.234). Scenario 2 envisions decreasing landfilled MSWI ash through their application in ceramics and glass/glass-ceramics production, which also improves the sustainability index (0.206). Scenario 3 suggests the use of MSWI ash in geotechnical applications including road construction, embankment and landfill cover materials, with a sustainability index of (0.159). Scenario 4 and 5 propose the utilization of BA/FA as alternative adsorbents and as fertilizers in agricultural soils respectively, which have a slight impact on the sustainability index (0.117) and (0.129).

Moreover, as seen in Figure 4, the highest weighted criteria are environmental impact and technical feasibility with 0.479 and 0.285 , whereas the lowest weighted crite-

TABLE 3: Average random consistency (Saaty, 2008; Al-Harbi, 2001).

\begin{tabular}{c|c|c|ccccccccccc}
$\boldsymbol{n}$ & $\mathbf{1}$ & $\mathbf{2}$ & $\mathbf{3}$ & $\mathbf{4}$ & $\mathbf{5}$ & $\mathbf{6}$ & $\mathbf{7}$ & $\mathbf{8}$ & $\mathbf{9}$ \\
\hline$R I$ & 0 & 0 & 0.58 & 0.9 & 1.12 & 1.24 & 1.32 & 1.41 & 1.45 & 1.49 \\
\hline
\end{tabular}


TABLE 4: Overall priority for scenarios with respect to the goal.

\begin{tabular}{l|c|c|c|c|c|c|c} 
Category & Sc. 0 & Sc. 1 & Sc. 2 & Sc. 3 & Sc. 4 & Sc. 5 \\
\hline Goal & 0.154 & 0.234 & 0.206 & 0.159 & 0.117 & 0.129 \\
\hdashline Order & 4 & 1 & 2 & 3 & 6 & 5 \\
\hline
\end{tabular}

ria include economy with 0.100 . As for the reasons behind the evident shortcoming of social aspects in criteria rankings (0.135), the relatively qualitative characteristics and conceptual intangibility of such a novel criterion come to mind. These are precisely the reasons Hacer AK and Washington Braida asserted in their study (Hacer AK, 2015) that among the sub-criteria related to environmental aspects, the impact on human health and water pollution were of solid importance compared to other sub-criteria. Similarly, among the sub-criteria under economic aspects, capital costs and market availability were relatively more important. Furthermore, landfill space saving and ease of monitoring were strongly more important than others among technical feasibility sub-criteria. Ultimately, upon weighing social aspects sub-criteria, it is understood that political concern, public acceptance, functionality, and usability are of relative importance.

The final step of the AHP modeling involves conducting a sensitivity analysis on the final outcome, using Expert Choice ${ }^{\circledR}$ sensitivity performance graph.

The performance sensitivity plot resulted from the Expert Choice ${ }^{\circledR}$ analysis in Figure 5 depicts the relative im-

TABLE 5: Selected criteria and sub-criteria for sustainable MSWI ash management.

\begin{tabular}{|c|c|c|}
\hline Criteria & Sub-criteria & Description \\
\hline \multirow[t]{10}{*}{ Environmental } & Wildlife Habitat & $\begin{array}{l}\text { How does the operation aim to protect, preserve and restore the habitat areas for wild } \\
\text { plants and animals. }\end{array}$ \\
\hline & $\mathrm{CO}_{2}$ Emissions & The potential Carbon dioxide levels generated from the MSWM scenarios. \\
\hline & Unpriced Ecosystem Services & $\begin{array}{l}\text { Recognizing all ecosystem services including those currently unpriced (e.g. pollination, } \\
\text { water regime maintenance, climate reliability and nutrient cycling). }\end{array}$ \\
\hline & Affecting Local and National Ecosystems & $\begin{array}{l}\text { How does the operation affect the capacity of the local ecosystem to deliver valued } \\
\text { ecosystem services reliably into the future (e.g. effects on water and air quality, and } \\
\text { wildlife habitat). }\end{array}$ \\
\hline & Availability of Resources & $\begin{array}{l}\text { How does the operation affect the long term availability of non-renewable and renew- } \\
\text { able resources. }\end{array}$ \\
\hline & Human Health & $\begin{array}{l}\text { How does the operation affect human health (including exposure to toxic substances } \\
\text { and sanitation issues). }\end{array}$ \\
\hline & Air Pollution & To what extent does this operation contribute to the air pollution \\
\hline & Water Pollution & $\begin{array}{l}\text { To what extent does this operation contribute to the water pollution (leachate produc- } \\
\text { tion into groundwater and reservoir for each MSWM scenario }\end{array}$ \\
\hline & Energy Consumption & Comparison of energy consumption for each MSWM scenario. \\
\hline & Water Consumption & Comparison of water consumption for each MSWM scenario. \\
\hline \multirow[t]{4}{*}{ Economy } & Capital Costs & $\begin{array}{l}\text { The cost to design, construct and expand new MSWM facilities and providing neces- } \\
\text { sary equipment, infrastructure, logistics and land. }\end{array}$ \\
\hline & Operating Costs & Yearly expenditures for fuel, maintenance, fringe benefits etc. \\
\hline & Market Availability & $\begin{array}{l}\text { The market demand for recycled materials, compost and electricity from MSWM } \\
\text { scenarios. }\end{array}$ \\
\hline & Government Subsidy & The probability of a government subsidy for each MSWM scenario. \\
\hline \multirow[t]{10}{*}{ Social } & Political Concern & The role of politics in MWSI ash management. \\
\hline & Public Acceptance & The aspect of public involvement in MSWM practices. \\
\hline & Negative Effects on the Producer Industry & How each MSWM scenario results in production decline in other producer industries \\
\hline & Contribution to Social Learning & Is the current scenario an advocate of an eco-friendly lifestyle \\
\hline & Flexibility and Adaptability & The potential of each MSWM scenario to adapt to change. \\
\hline & Functionality and Usability & How functional is the current MSWM scenario. \\
\hline & Modularity & $\begin{array}{l}\text { Is each MSWM scenario a self-reliant system and does it avoid over-connectedness } \\
\text { and associated relations of dependence subjected to shock }\end{array}$ \\
\hline & Intergenerational Equity & $\begin{array}{l}\text { How does the MSWM scenario affect potential costs and benefits for future genera- } \\
\text { tions. }\end{array}$ \\
\hline & Social Awareness & How does the MSWM scenario affect the social awareness of citizens. \\
\hline & Ecological Awareness & How does the MSWM scenario affect the ecological awareness of citizens. \\
\hline \multirow[t]{4}{*}{$\begin{array}{l}\text { Technical } \\
\text { Feasibility }\end{array}$} & Ease of Monitoring & $\begin{array}{l}\text { The act of monitoring the emissions and related impacts over time (Leaching, } \\
\text { Strength). }\end{array}$ \\
\hline & Lifetime & $\begin{array}{l}\text { A lifetime of the technical systems associated with the MSWM scenario and the total } \\
\text { required area for the MSWM technology. }\end{array}$ \\
\hline & Depreciation and Maintenance & Ease of technical systems maintenance in each MSWM scenario. \\
\hline & Landfill Space Saving & The ratio between waste not landfilled and total waste generated in a year. \\
\hline
\end{tabular}



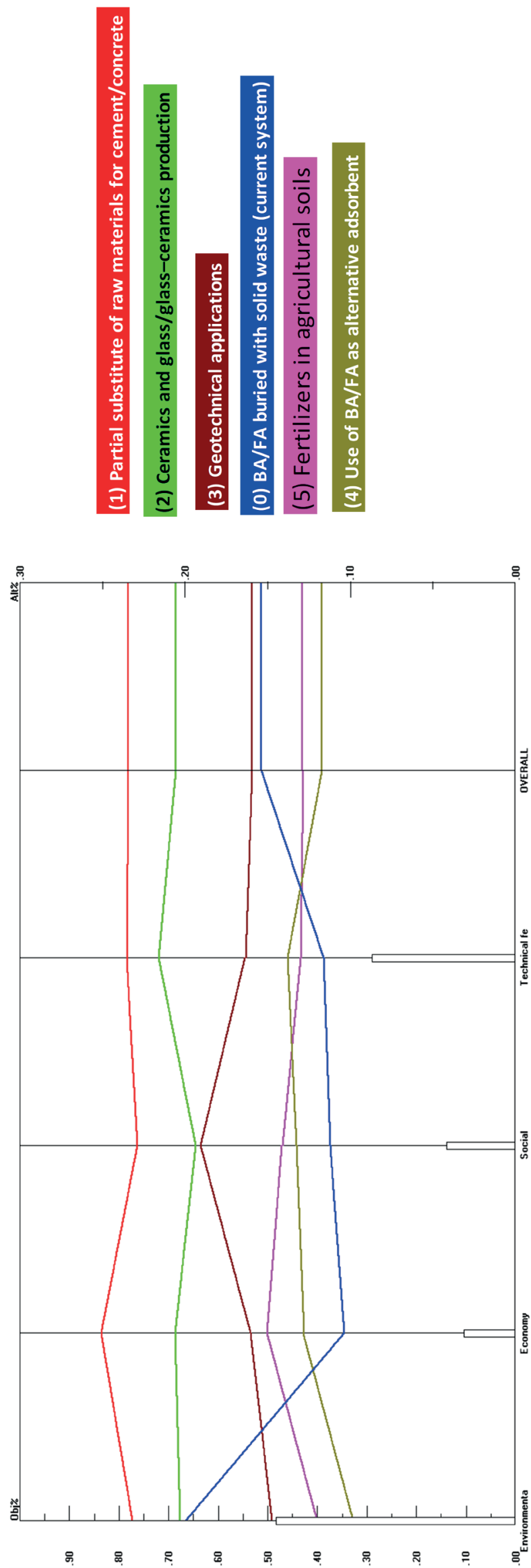

FIGURE 5: Performance sensitivity graph with respect to the goal. portance of each criterion as bars and the relative preference of each scenario as the intersection of the scenarios curves with the vertical line for each criterion. The overall scenario importance is indicated on the right. For this purpose, the change in scenario rankings by altering the relative importance of each criterion from $0 \%$ to $100 \%$ is exhibited in Table 6 and Table 7.

By decreasing the importance of environmental, economic, social aspects and technical feasibility to $0 \%$, scenarios 1 and 2 still rank top priorities and scenarios 5 and 4 score last. Via downgrading the relative importance of social aspects and technical feasibility, scenarios 3 and 0 swap priorities and scenario 3 drops below the currently practiced scenario 0 . This ranking swap occurs by virtue of scenario 0 scoring the lowest in social and technical feasibility. Through mitigating economical aspects, scenario 0 and 3 shared a common ranking. Ultimately, it is observed that minimizing the importance of environmental aspects has no evident effect on scenario rankings.

Similarly, by increasing the importance of each criterion to $100 \%$ so as to maximize its effective impact, the following can be observed. As shown in Table 7, it is recognized that Scenario 1, with the highest overall score, is the most sustainable approach to MSWM, largely due to the fact that the economic benefits and technical feasibility of Scenario 1 were more significant than that of any other proposed scenario. Furthermore, scenario 2 is regarded as the second most sustainable approach to MSWM, with a low impact on all criteria. Scenario 4 and 5 acquired the lowest overall score and demonstrate the lowest environmental impact due to pre-treatment impacts on the environment. Hence, it is concluded that scenario 4 and 5 do not provide the credentials to be regarded as suitable MSWM alternatives in Iran. Scenario 0 is ranked the fourth suitable option, albeit scoring the lowest in all aspects. This is primarily due to its moderate to strong score in environmental impacts.

\section{CONCLUSIONS}

In this study, a combination of MIVES and an AHP assessment model was developed in order to assess sustainability indexes regarding reusing MSWI ash. A hierarchy of four criteria and 28 sub-criteria was defined in this study as in to establish a comparison between six proposed scenarios for choosing the most suitable MSWI ash management in Iran. These criteria include environmental, economic, social aspects and technical feasibility.

The apparent uniqueness of this current study lies in the fact that it endeavored to formulate an extensive assessment tool. This precisely justifies the incorporation of the social criterion, a factor which is often dismissed in MSWM research in Iran. It is observable that the current scenario (scenario 0: BA/FA landfilled with solid waste) is not the ideal MSWM strategy due to its inefficiency in most aspects. Landfilling MSWI ash is economically deficient and prevents the reuse of potentially recyclable materials. Another issue revolving the commonly practiced landfilling actives in Iran, is the lack of procedural monitoring and standard compliance, which renders such actives environmentally counterproductive. 
TABLE 6: The relative weight by omitting factors separately.

\begin{tabular}{|c|c|c|c|c|c|c|c|c|}
\hline \multirow{2}{*}{ Criteria } & \multirow{2}{*}{$\begin{array}{l}\text { Change in relative } \\
\text { importance }\end{array}$} & \multicolumn{6}{|c|}{ The weighting of each scenario } & \multirow{2}{*}{ Ranking } \\
\hline & & Sc. 0 & Sc. 1 & Sc. 2 & Sc. 3 & Sc. 4 & Sc. 5 & \\
\hline Environment & decrease to $0 \%$ & $11.20 \%$ & $23.70 \%$ & $20.80 \%$ & $17.10 \%$ & $13.50 \%$ & $13.70 \%$ & $1>2>3>0>5>4$ \\
\hline Economy & decrease to $0 \%$ & $15.90 \%$ & $23.30 \%$ & $20.60 \%$ & $15.90 \%$ & $11.60 \%$ & $12.70 \%$ & $1>2>3=0>5>4$ \\
\hline Social & decrease to $0 \%$ & $16.00 \%$ & $23.50 \%$ & $20.80 \%$ & $15.50 \%$ & $11.50 \%$ & $12.70 \%$ & $1>2>0>3>5>4$ \\
\hline Technical feasibility & decrease to $0 \%$ & $16.90 \%$ & $23.40 \%$ & $20.20 \%$ & $15.80 \%$ & $10.90 \%$ & $12.90 \%$ & $1>2>0>3>5>4$ \\
\hline
\end{tabular}

TABLE 7: The relative weight by considering one factor

\begin{tabular}{|c|c|c|c|c|c|c|c|c|}
\hline \multirow{2}{*}{ Criteria } & \multirow{2}{*}{$\begin{array}{l}\text { Change in relative } \\
\text { importance }\end{array}$} & \multicolumn{6}{|c|}{ The weighting of each scenario } & \multirow{2}{*}{ Ranking } \\
\hline & & Sc. 0 & Sc. 1 & Sc. 2 & Sc. 3 & Sc. 4 & Sc. 5 & \\
\hline Environment & increase to $100 \%$ & $19.90 \%$ & $23.20 \%$ & $20.30 \%$ & $14.70 \%$ & $9.80 \%$ & $12.00 \%$ & $1>2>0>3>5>4$ \\
\hline Economy & increase to $100 \%$ & $10.40 \%$ & $25.10 \%$ & $20.60 \%$ & $16.00 \%$ & $12.80 \%$ & $15.00 \%$ & $1>2>3>5>4>0$ \\
\hline Social & increase to $100 \%$ & $11.20 \%$ & $22.90 \%$ & $19.40 \%$ & $19.10 \%$ & $13.30 \%$ & $14.10 \%$ & $1>2>3>5>4>0$ \\
\hline Technical feasibility & increase to $100 \%$ & $11.60 \%$ & $23.50 \%$ & $21.60 \%$ & $16.40 \%$ & $13.80 \%$ & $13.00 \%$ & $1>2>3>4>5>0$ \\
\hline
\end{tabular}

The results revealed partial substitute of raw materials for cement/concrete (Scenario 1) as the top alternative solution. The main factors underlying such an outcome, are the economic and ecological advantages of BA/FA mixed cement throughout its life-cycle. The cost-effectiveness of partially replacing a high-value product like cement with treated MSWI ashes has a great impact on the cement industry, one of Iran's most vital industries.

According to the judgements, the utilization of BA/FA as alternative adsorbents and as fertilizers in agricultural soils (Scenarios 4 and 5) are not to be currently pursued in Iran given that they do not result in environmental or economic advantages, and that there are many principal difficulties involved in developing such applications and doubts about controlling their impact on human health. The common denominator in the shortcoming of either application is the leachability of heavy metals from MSWI ashes. The leaching of heavy metals in the ground water produces serious pollution loads in the already heavily polluted water regime of the country and water pollution is a subject of national sensitivity in Iran, especially in the wake of the nation's imminent widespread water shortages. Moreover, reusing waste residues as alternative fertilizers face strong public opinion, specifically due to a recent growing predilection for organic products.

Moreover, the current study only attempted to evaluate MSWM scenarios using the sustainability index and did not integrate resilience based criteria into the sustainability assessment to invoke a respect for socio-ecological system complexity. Nevertheless, resilience itself is a subject of intrinsic complexity and requires on-going implementation data and iterative operation improvement as analysis inputs, which are currently unavailable in Iran. Hence, the incorporation of resilience-based criteria and sustainability assessment demands further development and calls for extensive future work.

\section{ACKNOWLEDGEMENTS}

The authors wish to thank the experts for taking the time to fill out the AHP questionnaires.

\section{REFERENCES}

Aguado de Cea, A., Gálvez, J.C. and Fernández-Ordoñez, D. (2016) Sustainability evaluation of the concrete structures. http://www. iccs16.org/frontal/doc/Ebook_ICCS16.pdf.

Aguado de Cea, A., Gálvez, J. C., \& Fernández-Ordoñez, D. (2016). Sustainability evaluation of the concrete structures. In ICCS16 Concrete Sustainability: Proceedings of the Second International Conference on Concrete Sustainability, held in Madrid, Spain on 13-15 June 2016 (pp. 58-71). Centre Internacional de Mètodes Numèrics en Enginyeria (CIMNE).

Al-Harbi, K. M. A. S. (2001). Application of the AHP in project management. International Journal of Project Management, 19(1), 19-27. http://doi.org/10.1016/S0263-7863(99)00038-1

Allegrini, E., Vadenbo, C., Boldrin, A., \& Fruergaard, T. (2015). Life cycle assessment of resource recovery from municipal solid waste incineration bottom ash. Journal of Environmental Management, 151, 132-143. http://doi.org/10.1016/j.jenvman.2014.11.032

Barros, M.C. (n.d.). Integrated pollution prevention and control for heavy ceramic industry in Galicia (NW Spain).

Barros, J.J.C., Coira, M. L., De la Cruz López, M. P., \& del Caño Gochi, A. (2015). Assessing the global sustainability of different electricity generation systems. Energy, 89, 473-489.

Blanco, A., de la Fuente, A., \& Aguado, A. (n.d.). Sustainability analysis of steel fibre reinforces concrete slabs, 850-861.

Brauers, W. K. (2004). OPTIMIZATION METHODS FOR (Vol. 342). Kluwer Academic Publishers, Boston/Dordrecht/London.

Chang, K. L. (2015). A hybrid program projects selection model for nonprofit TV stations. Mathematical Problems in Engineering, 2015.

Chandler, A. J., Eighmy, T. T., Hjelmar, O., Kosson, D. S., Sawell, S. E., Vehlow, J., ... \& Hartlén, J. (1997). Municipal solid waste incinerator residues (Vol. 67). Elsevier.

Chen, X., Pang, J., Zhang, Z., \& Li, H. (2014). Sustainability assessment of solid waste management in China: A decoupling and decomposition analysis. Sustainability, 6(12), 9268-9281.

Chen, Y. C., Lien, H. P., \& Tzeng, G. H. (2010). Measures and evaluation for environment watershed plans using a novel hybrid MCDM model. Expert systems with applications, 37(2), 926-938.

Chithambaranathan, P., Subramanian, N., Gunasekaran, A., \& Palaniappan, P. K. (2015). Service supply chain environmental performance evaluation using grey based hybrid MCDM approach. International Journal of Production Economics, 166, 163-176.

Colangelo, F., Cioffi, R., Montagnaro, F., \& Santoro, L. (2012). Soluble salt removal from MSWI fly ash and its stabilization for safer disposal and recovery as road basement material. Waste management, 32(6), 1179-1185.

Dong, J., Chi, Y., Zou, D., Fu, C., Huang, Q., \& Ni, M. (2014). Energy-environment-economy assessment of waste management systems from a life cycle perspective: Model development and case study. Applied Energy, 114, 400-408. 
Ferreira, C., Ribeiro, A., \& Ottosen, L. (2003). Possible applications for municipal solid waste fly ash. Journal of Hazardous Materials, 96(2-3), 201-216. http://doi.org/10.1016/S0304-3894(02)00201-7

Forteza, R., Far, M., Segu, C., \& Cerda, V. (2004). Characterization of bottom ash in municipal solid waste incinerators for its use in road base. Waste Management, 24(9), 899-909. http://doi. org/10.1016/j.wasman.2004.07.004

de la Fuente, A., Pons, O., Josa, A., \& Aguado, A. (2016). Multi-Criteria Decision Making in the sustainability assessment of sewerage pipe systems. Journal of Cleaner Production, 112, 4762-4770.

de la Fuente, A., Armengou, J., Pons, O., \& Aguado, A. (2017). Multicriteria decision-making model for assessing the sustainability index of wind-turbine support systems: application to a new precast concrete alternative. Journal of Civil Engineering and Management, 23(2), 194-203.

de la Fuente, A., Blanco, A., Cavalaro, S., \& Aguado, A. (n.d.). Sustainability assessment of precast concrete segments for TBM tunnels.

Garcia-Lodeiro, I., Carcelen-Taboada, V., Fernández-Jiménez, A., \& Palomo, A. (2016). Manufacture of hybrid cements with fly ash and bottom ash from a municipal solid waste incinerator. Construction and Building Materials, 105, 218-226. http://doi.org/10.1016/j. conbuildmat.2015.12.079

Ginés, O., Chimenos, J. M., Vizcarro, A., Formosa, J., \& Rosell, J. R. (2009). Combined use of MSWI bottom ash and fly ash as aggregate in concrete formulation: Environmental and mechanical considerations, 169, 643-650. http://doi.org/10.1016/j. jhazmat.2009.03.141

Hacer Ak, W. B. (n.d.). Sustainable municipal solid waste management decision making. Management of Environmental Quality: An International Journal, Vol. 26 Issue: 6, pp.909-928, doi: 10.1108/ MEQ03-2015-0028. http://doi.org/10.1108/ MEQ-03-2015-0028

Henrik Ørnebjerg ; Jörn, F. (2006). "Management of Bottom Ash from WTE Plants." Working Group on Thermal Treatment of Waste, The International Solid Waste Association (ISWA).

Hoornweg, D., \& Bhada-tata, P. (2012). What a waste: A global review of solid waste management. Urban Development Series Knowledge Papers. http://doi.org/10.1111/febs.13058

Hosseini, S. M. A., Pons, O., \& De, A. (2018). A combination of the Knapsack algorithm and MIVES for choosing optimal temporary housing site locations: A case study in Tehran. International Journal of Disaster Risk Reduction, 27(October 2017), 265-277. http://doi. org/10.1016/j.ijdrr.2017.10.013

http://stats.oecd.org/. (n.d.).

Huang, T. Y., Chiueh, P. T., \& Lo, S. L. (2015). Life-cycle environmental and cost impacts of reusing fly ash. Resources, Conservation and Recycling. http://doi.org/10.1016/j.resconrec.2016.07.001

llangkumaran, M., Karthikeyan, M., Ramachandran, T., Boopathiraja, M., \& Kirubakaran, B. (2015). Risk analysis and warning rate of hot environment for foundry industry using hybrid MCDM technique. Safety science, $72,133-143$.

Ishizaka, A., \& Labib, A. (2009). Analytic hierarchy process and expert choice: Benefits and limitations. Or Insight, 22(4), 201-220.

Khajuria, A., Yamamoto, Y., \& Morioka, T. (2010). Estimation of municipal solid waste generation and landfill area in Asian developing countries.

Lam, C. H., Ip, A. W., Barford, J. P., \& McKay, G. (2010). Use of incineration MSW ash: a review. Sustainability, 2(7), 1943-1968.

Li, Y., Hao, L., \& Chen, X. (2016). Analysis of MSWI bottom ash reused as alternative material for cement production. Procedia Environmental Sciences, 31, 549-553. http://doi.org/10.1016/j.proenv.2016.02.084

Liou, J. J., \& Tzeng, G. H. (2012). Comments on "Multiple criteria decision making (MCDM) methods in economics: an overview". Technological and Economic Development of Economy, 18(4), 672-695.

Lombera, J. T. S. J., \& Rojo, J. C. (2010). Industrial building design stage based on a system approach to their environmental sustainability. Construction and Building Materials, 24(4), 438-447.

Management of Bottom Ash from WTE Plant. 2006, Working Group on Thermal Treatment of Waste, The International Solid Waste Association (ISWA)

Margallo, M. (2015). Environmental sustainability assessment of the management of municipal solid waste incineration residues: A review of the current situation. Clean Technologies and Environmental Policy, 17(5). http://doi.org/10.1007/s10098-015-0961-6
Margallo, M., Aldaco, R., Irabien, A., Varbanov, P., Klemes, J. J., Seferlis, P., ... Pierucci, S. (2013). Life Cycle Assessment of Bottom Ash Management from a Municipal Solid Waste Incinerator (MSWI). 16th International Conference on Process Integration, Modelling and Optimisation For Energy Saving and Pollution Reduction (Pres'13), 35, 871-876. http://doi.org/10.3303/CET1335145

Margallo, M. Massoli Taddei, M.B., Hernández-Pellón, A., Aldaco R. \& Irabien A. (2015). Environmental sustainability assessment of the management of municipal solid waste incineration residues : a review of the current situation, 1333-1353. http://doi.org/10.1007/ s10098-015-0961-6

Marković, D., Janošević, D., Jovanović, M. L., \& Nikolić, V. (2010). Application method for optimization in solid waste management system in the city of Niš. Facta universitatis-series: Mechanical Engineering, 8(1), 63-76.

Moeinaddini, M., Khorasani, N., Danehkar, A., \& Darvishsefat, A. A (2010). Siting MSW landfill using weighted linear combination and analytical hierarchy process (AHP) methodology in GIS environment (case study: Karaj). Waste management, 30(5), 912-920.

Nabavi-Pelesaraei, A., Bayat, R., Hosseinzadeh-Bandbafha, H., Afrasyabi, H., \& Berrada, A. (2017). Prognostication of energy use and environmental impacts for recycle system of municipal solid waste management. Journal of Cleaner Production, 154, 602-613.

Oehmig, W. N., Roessler, J. G., Blaisi, N. I., \& Townsend, T. G. (2015). ScienceDirect Contemporary practices and findings essential to the development of effective MSWI ash reuse policy in the United States. Environmental Science and Policy, 51, 304-312. http://doi. org/10.1016/j.envsci.2015.04.024

Pardo-Bosch, F., \& Aguado, A. (2016). Sustainability as the key to prioritize investments in public infrastructures. Environmental Impact Assessment Review, 60, 40-51.

Pérez, J. (1995). Some Comments on Saaty's AHP. Management Science, 41(6), 1091-1095. http://doi.org/10.1287/mnsc.41.6.1091

Piñero, I., San-José, J. T., Rodríguez, P., \& Losáñez, M. M. (2017). Multicriteria decision-making for grading the rehabilitation of heritage sites. Application in the historic center of La Habana. Journal of Cultural Heritage, 26, 144-152.

Pires, A., Martinho, G., \& Chang, N. B. (2011). Solid waste management in European countries: A review of systems analysis techniques. Journal of environmental management, 92(4), 1033-1050.

Pons, O., \& Aguado, A. (2012). Integrated value model for sustainable assessment applied to technologies used to build schools in CataIonia, Spain. Building and Environment, 53, 49-58.

Pons, O., de la Fuente, A., \& Aguado, A. (2016). The use of MIVES as a sustainability assessment MCDM method for architecture and civil engineering applications. Sustainability, 8(5), 460.

Poulikakos, L. D., Papadaskalopoulou, C., Hofko, B., Gsch??sser, F. Cannone Falchetto, A., Bueno, M., ... Partl, M. N. (2017). Harvesting the unexplored potential of European waste materials for road construction. Resources, Conservation and Recycling. http://doi. org/10.1016/j.resconrec.2016.09.008

Pujadas, P., Pardo-Bosch, F., Aguado-Renter, A., \& Aguado, A. (2017) MIVES multi-criteria approach for the evaluation, prioritization, and selection of public investment projects. A case study in the city of Barcelona. Land Use Policy, 64, 29-37.

Saaty, T. L. (2008). Decision making with the analytic hierarchy process. International Journal of Services Sciences. http://doi. org/10.1504/IJSSCI.2008.017590

Schübeler, P., Christen, J., \& Wehrle, K. (1996). Conceptual framework for municipal solid waste management in low-income countries (Vol. 9). St. Gallen: SKAT (Swiss Center for Development Cooperation).

Sabbas, T., Polettini, A., Pomi, R., Astrup, T., Hjelmar, O., Mostbauer, P. ... \& Heuss-Assbichler, S. (2003). Management of municipal solid waste incineration residues. Waste management, 23(1), 61-88.

Silva, A., Rosano, M., Stocker, L., \& Gorissen, L. (2016). From waste to sustainable materials management: Three case studies of the transition journey. Waste Management, 1-11. http://doi. org/10.1016/j.wasman.2016.11.038

Sormunen, L. A. (2016). Combining Mineral Fractions of Recovered MSWI Bottom Ash: Improvement for Utilization in Civil Engineering Structures. http://doi.org/10.1007/s12649-016-9656-4

Sou, W., Chu, A., \& Chiueh, P. (2016). Sustainability assessment and prioritisation of bottom ash management in Macao. Waste Management \& Research, 34(12), 1275-1282. http://doi. org/10.1177/0734242X16665914 
Sun, X., Li, J., Zhao, X., Zhu, B., \& Zhang, G. (2016). A Review on the Management of Municipal Solid Waste Fly Ash in American. Procedia Environmental Sciences, 31, 535-540. http://doi.org/10.1016/j. proenv.2016.02.079

Talyan, V., Dahiya, R. P., \& Sreekrishnan, T. R. (2008). State of municipal solid waste management in Delhi, the capital of India. Waste Management, 28(7), 1276-1287.

Tasneem, K. (2014). B. U. of M. S. W. I. A. as S. R. C. M. (2014). Beneficial Utilization of Municipal Solid Waste Incineration Ashes.

Tavana, M., Momeni, E., Rezaeiniya, N., Mirhedayatian, S. M., \& Rezaeiniya, H. (2013). A novel hybrid social media platform selection model using fuzzy ANP and COPRAS-G. Expert Systems with Applications, 40(14), 5694-5702

Travar, I., Lidelöw, S., Andreas, L., Tham, G., \& Lagerkvist, A. (2009). Assessing the environmental impact of ashes used in a landfill cover construction. Waste Management, 29(4), 1336-1346. http://doi. org/10.1016/j.wasman.2008.09.009

U.S. EPA. (2016). Assessing Trends in Material Generation, Recycling, Composting, Combustion with Energy Recovery and Landfilling in the United States.
Vehlow, J. (2012). Waste-to-energy ash management in Europe. In Encyclopedia of Sustainability Science and Technology (pp. 11720-11736). Springer, New York, NY.

Wang, S., \& Wu, H. (2006). Environmental-benign utilisation of fly ash as low-cost adsorbents. Journal of Hazardous Materials. http:// doi.org/10.1016/j.jhazmat.2006.01.067

Wiles, C., \& Shepherd, P. B. (1999). Beneficial use and recycling of municipal waste combustion residues: a comprehensive resource document.

Yin, L. J., Wang, C., Hu, Y. Y., Chen, D. Z., Xu, J. F., \& Liu, J. (2017). AHPbased approach for optimization of waste disposal method in urban functional zone. Environmental technology, 38(13-14), 16891695.

Zavadskas, E. K., Antucheviciene, J., Turskis, Z., \& Adeli, H. (2016). Hybrid multiple-criteria decision-making methods: A review of applications in engineering. Scientia Iranica. Transaction A, Civil Engineering, 23(1), 1

Zavadskas, E. K., \& Turskis, Z. (2011). Multiple criteria decision making (MCDM) methods in economics: an overview. Technological and economic development of economy, 17(2), 397-427. 